\title{
On the Vascular Anatomy of the Young Epicotyl in some Ranalean Forms.
}

\author{
BY
}

\author{
KATHLEEN B. BLACKBURN, \\ Lecturer in Botany, Southlands Training College.
}

With Plate XIII and nineteen Figures in the Text.

$\mathrm{T}$ $\mathrm{HE}$ present paper is an account of some work which has been carried out at Bedford College under the direction of Dr. Thomas. It forms part of a series of investigations into the anatomy of the axis in seedling Dicotyledons, and in particular into that of the epicotyl.

In Ranalean forms the anatomical features of the mature axis have been studied from various points of view by numerous workers, notably by Marié, ${ }^{1}$ by members of the Liège School, ${ }^{2}$ and by Worsdell, ${ }^{3}$ but the beginnings of vascular development in the seedling epicotyl have received far less attention.

The 'Contributions à l'anatomie des Renonculacées', published by the Liège School, comprise monographs on certain Ranunculaceous genera (Clematis, Delphinium, Thalictrum, and Ranunculus arvensis), in which detailed accounts of the plumular anatomy are included.

In his work on the 'Morphology of the Central Cylinder in Angiosperms' Professor Jeffrey ${ }^{4}$ describes and figures early stages of the vascular structure in young stems of members of the families Nymphaeaceae and Ranunculaceae (Ranunculus and Anemone spp.).

Professor Gwynne-Vaughan ${ }^{5}$ has described early stages of members of

1 Marié, P.: Recherches sur la Structure des Renonculacées. Ann. Sci. Nat., Bot., tome xx, 1884 .

2 Contributions à l'anatomie des Renonculacées : I892.

Nihoul, E.: Ramunculus arvensis. Mém. pub. par l'Acad. Roy. de Belgique, Brux., tome lii,

Lenfant, C. : Le Genre Delphinium. Mém. Soc. Roy. des Sciences de Liège, sér. 2, t. xix, I 897.

Mansion, A. : Le Genre Thalictrum. Mém. Soc. Roy. des Sciences de Liège, sér. 2, t. xx, 1898 .

Sterckx, R. : La Tribu des Clématidées. Mém. Soc. Roy. des Sciences de Liège, sér. 2, t. xx, I 898.

3 Worsdell : A Study of the Vascular System in certain Orders of the Ranales. Ann. of Bot., vol. xxii, October, I908.

4 Jeffrey: The Morphology of the Central Cylinder in Angiosperms. Trans. Canad. Inst., vol. vi, Toronto, I889.

5 Gwynne-Vaughan, D. T.: On some Points in Morphology and Anatomy of Nymphaeaceae. Trans. Linn. Soc., vol. v, pt. 7, 1897 .

[Annals of Botany, Vo1. XXXI. No. CXXI. January, 1917.] 
the Nymphaeaceae in his investigation of the development of polystely in this family.

In view of the great interest attaching to the Ranales on general grounds, ${ }^{1}$ and to the Ranunculaceae in particular through the possession of the tubular type of stele to which Professor Jeffrey ${ }^{2}$ attaches so much importance, it was suggested that a comparative investigation of Ranalean plumular anatomy in its early stages could hardly fail to yield results of some interest. A nucleus of material was handed over to the writer by Dr. Thomas, and has been supplemented by seedlings raised in the Botany garden of Bedford College, and in the case of many of the British species by those obtained in the field.

Owing to difficulties in obtaining adequate material for a full study of the other families, Ranunculaceae has received the most attention.

The axes of seedlings bearing from one to five expanded foliage leaves, in addition to the cotyledons, were microtomed from the stem apex to the upper part of the hypocotyl.

The seedling morphology shows a number of general features, one or more of which may be departed from in individual cases, though on the whole they are very constant throughout the group.

The first few internodes are relatively short, and the phyllotaxis is twofifths. The cotyledons are epigeal and, where the first internode is specially short, the first two foliage leaves tend to be opposite and at right angles to the cotyledons. A cotyledonary tube is frequently found.

With the exception of the very specialized Nymphaeaceae ${ }^{3}$ the divergence from the type just described is in very limited and definite directions :

(a) In Calycanthus and in some species of Clematis the early foliage leaves are opposite and decussate, and in Anona the phyllotaxis is one-half.

(b) Hypogeal germination is found in certain large-seeded forms. It occurs throughout Lauraceae and Anonaceae and in certain species of Ranunculaceae, notably Anemone nemorosa and some species of Paeonia and Clematis (see Text-figs. 3 and 9).

(c) The cotyledonary tube varies in extent. It is practically absent in Thalictrum, but it is well marked in Anemone fulgens, Podophyllum emodi, and Eranthus hiemalis (see Text-fig. 4). In Anemone apennina and Ramunculus Ficaria there is only one lobed cotyledonary member.

As has been pointed out by Miss Sargant, ${ }^{4}$ a tuberous swelling of the hypocotyl and accompanying suppression of the first few plumular internodes is frequently correlated with a long cotyledonary tube. Accordingly this

\footnotetext{
1 See Arber, E. A. Newell, and Parkin, J.: On the Origin of Angiosperms. Journ. Linn. Soc., vol. $\mathrm{xxxviii,} \mathrm{I907.}$

2 See Jeffrey, loc. cit. $\quad 3$ See Gwynne-Vaughan, loc. cit.

4 Sargant, E.: A Theory of the Origin of Monocotyledons, \&c. Ann. of Bot., vol. xvii, I903, p. 77 .
} 
feature is found in all the species mentioned above with the exception of Anemone fulgens, and also in A. nemorosa (see Text-fig. 3).

There is a corresponding general type of anatomy to which the majority of the seedlings described conform, though there are more variants from it than from the common type of morphology.

Each foliage leaf contributes three traces to the axial vascular cylinder, which consists of a circle of separate collateral bundles anastomosing at the nodes. Early cambial activity connects the strands by secondary tissue. The number of primary bundles in subsequent internodes varies with the species, but in the lowest plumular internode there are usually six. These arrange themselves in groups of three on either side of the plane passing through the centre of the two cotyledons, which will be referred to as the cotyledonary plane.

In general the cotyledons each contribute a double bundle, and thus a ring of strands is again completed (see Text-fig. 6). The three plumular and two half cotyledonary strands on each side then fuse, to give what often appears to be a single pair of collateral bundles, on the flanks of the diarch plate. This is usually formed quite high up in the hypocotyl, as described by Dr. Thomas. ${ }^{1}$

Some of the forms described possess independent lateral strands at the base of the cotyledons, and in the case, for instance, of Ranunculus arvensis the insertion of their traces is so remarkably like the insertion of the plumular traces in the same species, both as regards the number of strands from each cotyledon and their mode of entry, that one is tempted to suggest the possibility that this is the earlier condition for the cotyledons. The insertion of three strands from each cotyledon is in some cases connected with a tetrarch root, but in the plant referred to the lateral strands die out in the upper part of the hypocotyl. The anatomical similarity between leaf and cotyledon is here borne out by the existence of a series of leaf forms intermediate between the compound leaf of the adult plant and the simple ovate cotyledon.

Just as there were forms whose morphology differed from the general ground plan, so the same or other forms may be aberrant in respect to anatomy.

(a) Those forms of Clematis seedling whose foliage leaves are opposite show a reduction in the number of strands in the internode, four only being present. The insertion of the leaf-trace strands is also exceptional.

(b) In the species presenting both hypogeal and epigeal germination, as in Clematis, it is found that this feature has no anatomical consequences.

(c) The tuberous habit causes anatomical modifications in several

1 Thomas, E. N.: Seedling Anatomy of Ranales, Rhoeadales, and Rosales. Ann. of Bot, vol. xxviii, October, 1914 . 
different directions in the various species showing that peculiarity. An interesting form is to be found in Anemone apennina and Eranthis hiemalis.

Near the periphery of the tuber is a ring of bundles of plumular origin, in the latter case connected by a well-marked cambium. The cotyledonary traces and some plumular tissue (in $A$. apennina) form a quite separate medullary system. These two groups of vascular tissue join at the base of the tuber.

The other anatomical variations are not so directly correlated with the morphology.

(d) The number of strands contributed by each leaf, though prevailingly three, is not always so. The first foliage leaf of Paeonia arborea has five traces at its base, whereas quite frequently, in Anemone sylvestris and many other seedlings, the strands of the first and sometimes more leaves are reduced to one at the point of insertion. This may be compared with the one double bundle found in the cotyledons, and is probably directly correlated with a reduction in the size of the leaf.

(e) The age at which cambial growth first appears is another feature which varies greatly. In Nigella hispanica, an annual form, it is first seen at a very late date and does not show great activity, whereas in Aconitum Wilsonii the very small amount of primary xylem in the bundles is scarcely differentiated before a complete ring of cambium is present (see Text-fig. 7). It seems possible that the date of appearance of the cambium may be directly correlated with the amount of primary tissue in the bundles.

$(f)$ The most conspicuous exception to the general type of seedling anatomy is that found in the genera Ramunculus, Trollius, and Caltha. This is described by Professor Jeffrey ${ }^{1}$ in the genus Ramunculus and in the young rhizomes of Anemone pennsylvanica. It consists of a tubular stele interrupted by leaf-gaps and bounded both internally and externally by a more or less well-marked endodermis, which may, however, be quite absent. The evidence brought forward in this paper suggests that the tubular nature of the stele may be a secondary phenomenon. The significance of the internal endodermis will be discussed later.

Thus, with a few exceptions, the structure of the seedling, both as regards morphology and anatomy, is constant throughout the group, whereas there is considerable diversity in the adult, and this diversity may be found in forms whose seedlings show great similarity,

A consideration of the three genera Aquilegia, Thalictrum, and Anemone, serves to illustrate this point. With the exception of the two tuberous species of Anemone, all the seedlings of these genera that have been examined show a remarkable anatomical resemblance to one another, even in histological details, while there are marked differences in the adult anatomy. 
In Aquilegia there is a single ring of bundles with fascicular cambium only, whereas in Thalictrum they are arranged in two or three concentric circles. Anemone shows various forms of anatomy in the different species. There is commonly a somewhat irregular ring of bundles, but medullary bundles and separate endodermal sheaths are among the anomalies found.

The descriptions of the adult anatomy of the forms described are taken, for the most part, from the published works of M. Marié and Mr. Worsdell.

\section{RANUNCULACEAE.}

Aquilegia. Marié states that there is a ring of bundles with a wellmarked fascicular cambium in the adult stem of Aquilegia. Small intercalary bundles are also present. The seedlings are small and somewhat wiry in texture. The plumular internodes of the seedling are very short and hidden by the sheathing bases of the foliage leaves, which have long petioles and consist of three practically sessile leaflets. The phyllotaxis is twofifths. The cotyledons are ovate and stalked and are joined below to form a short cotyledonary tube (see Text-fig. I). Three species, $A$. vulgaris, A. alpina, and $A$. canadense, have been examined, of which the first is somewhat larger, but otherwise they show almost identical features both morphologically and anatomically. The vascular cylinder consists of a ring of about twelve strands. Secondary thickening begins at an early age (see Pl. XIII, Fig. I). The sheathing bases of the foliage leaves overlap and so completely encircle everything within them. Each plumular leaf supplies three bundles to the central cylinder, and these enter the ring at an angle

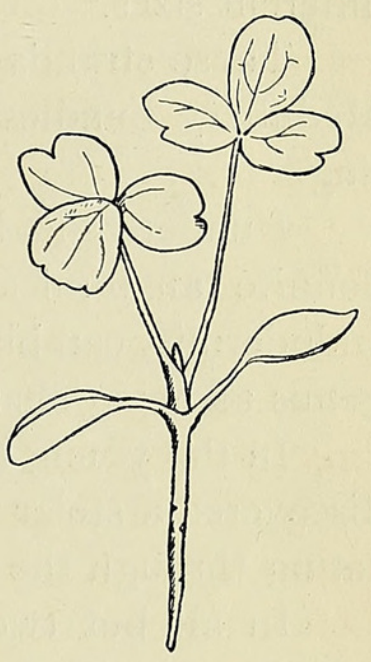

TeXt-fig. I. Aquilegia vulgaris. $\times \frac{1}{2}$. of about $120^{\circ}$ from one another, so that the lateral strands of adjacent leaves cross. The plumular bundles are reduced to six above the cotyledonary node, and these strands arrange themselves in groups of three on either side of the cotyledonary plane (see Pl. XIII, Fig. 2). The double bundles from the cotyledons are inserted between these two groups, which then rapidly become reduced to single bundles. The phloem groups from the cotyledonary strands fuse with the plumular phloems and a diarch arrangement is attained. The pith and plumular tissue rapidly decrease as the lower levels of the hypocotyl are reached and typical root structure appears.

Thalictrum. This genus has been very fully studied from an anatomical point of view by M. Mansion. ${ }^{1}$ A very large number of bundles are arranged in the aerial parts of the adult stem in such a way as to resemble 
strongly that of a monocotyledon. The seedlings of the genus have been described by M. Mansion in the paper referred to above. The young plants differ from those of Aquilegia in having petioles to the plumular leaflets. The anatomical features of the four species examined, namely, $T$. javanicum, $T$. flavum, $T$. glaucum, and T. adiantifolium, are very similar in the seedling stage. The vascular cylinder consists of a ring of bundles, and at each node three separate leaf-trace strands are inserted. At the cotyledonary node are the usual six plumular bundles, besides the entering cotyledonary traces, which, though single higher up, show their double nature at this level. The anatomy thus closely resembles that of the genus Aquilegia, and the general type described for the order.

Anemone. The adult anatomy in this genus has been studied in detail by M. Janczewski ${ }^{1}$ and less fully by M. Marié. The latter, in summing up for the genus, says that the cauline bundles are in one circle though of different sizes. ${ }^{2}$

These strands may be surrounded by individual endodermal sheaths. Medullary bundles are found in some species in addition to the normal ring.

I understand M. Janczewski to state that the habit of the stem has definite anatomical consequences influencing the presence or absence of endodermis, cambium, and mechanical tissue. Mr. Sinnott speaks of the genus as being characterized by a multilacunar leaf-trace insertion. ${ }^{3}$

In the young hypogeal stem of $A$. pennsylvanica, Professor Jeffrey has discovered a stelar tube with internal and external phloeoterma communicating through the leaf-gaps.

In all but two of the species examined the seedling anatomy corresponds very closely to that of Aquilegia, though the morphological features show a large range of variation. Most species of Anemone have a cotyledonary tube, and associated with this, in $A$. apennina, there is a tuberous hypocotyl. In another species, $A$. nemorosa, the tuberous habit is found in connexion with the hypogeal germination.

Anemone montana. This is a small seedling in general habit resembling Aquilegia, but with trifid foliage leaves. The internal structure is correspondingly similar to that of Aquilegia. Cambial growth is not present in the strands at the leaf base, but is clearly marked and quite diagrammatic in the axis at an early stage.

The lateral strands of the trifascicular trace are nearer the median one at the node than in the last two genera, so that those of subsequent leaves do not so frequently overlap. 1898 .

1 Janczewski: Étude morphologique sur le genre Anemone. Rev. Gén. de Bot., vol. x

${ }^{2}$ Loc. cit., p. 167.

${ }^{3}$ Sinnott, E. W.: The Anatomy of the Node as an Aid in the Classification of Angiosperms. Am. Journ. of Bot., vol. i, July, 1914, p. 312. 
The lateral strands usually join the vascular axis at a slightly higher level than does the central strand. This is particularly noticeable in connexion with the first foliage leaf, whose median strand is inserted at the level of the cotyledons, whereas the laterals have entered the ring considerably above.

$A$. vernalis possesses a somewhat smaller seedling, and the foliage leaves are trilobed at the tip. It differs from the last species in several particulars. There is an earlier inception of cambial growth giving a compact ring of merismatic secondary tissue. The pith is smaller. The first internode is relatively long, and in it the plumular strands collect up to form a single pair of rather wide bundles in the intercotyledonary plane. Root structure is rapidly attained.

In $A$. vitifolia the early leaves are more cut up. The structure is intermediate between the two forms already described. In one of the seedlings examined the first foliage leaf contributes only one strand to the vascular cylinder (see Text-fig. 2, strand $a$ ).

Anemone virginiana appeared to be similar, though the seedlings were very young. Secondary thickening is instituted comparatively late, as it had not yet appeared in any of the seedlings examined.

A. pulsatilla resembles $A$. montana in external appearance, whereas its anatomy is nearer to

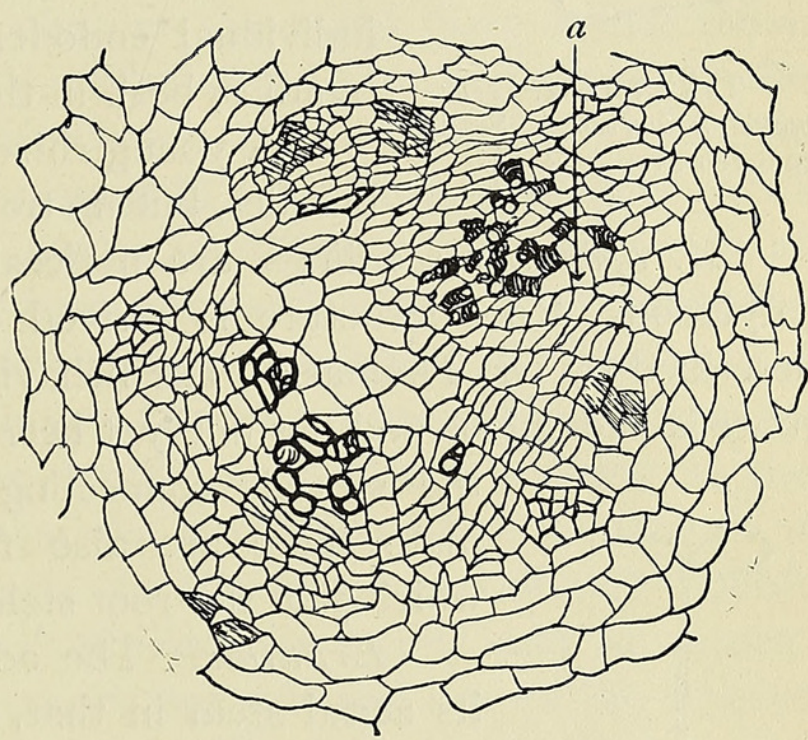

TeXT-Fig. 2. Anemone vitifolia. First plumular node. that of $A$. vernalis.

A. fulgens. The cotyledonary tube is about half an inch long at the time the plumule breaks through it at the base. The foliage leaves are larger and have longer petioles than in the previous species. Anatomically the species is peculiar in an extreme telescoping of the young axis. The median strands of the first two foliage leaves and the double bundles from the cotyledons all converge at the same level, giving a cruciform appearance at the cotyledonary node. The two laterals of the second foliage leaf and a single one from the first foliage leaf are inserted at two levels higher up in the axis.

$A$. rivularis is a larger seedling, but its anatomy corresponds closely with that of $A$. vernalis.

A. sylvestris is a smaller seedling, and the small oval laminae of the cotyledons are attached directly to the cotyledonary tube. The lateral 
strands of the first few foliage leaves are absent, but otherwise the seedling agrees with the other species in its anatomical features.

The two other species examined form tubers at a very early age.

A. nemorosa possesses two sessile hypogeal cotyledons (see Text-fig. 3). The epicotyledonary axis does not elongate, and but a single foliage leaf is formed at the apex of the tuber during the first

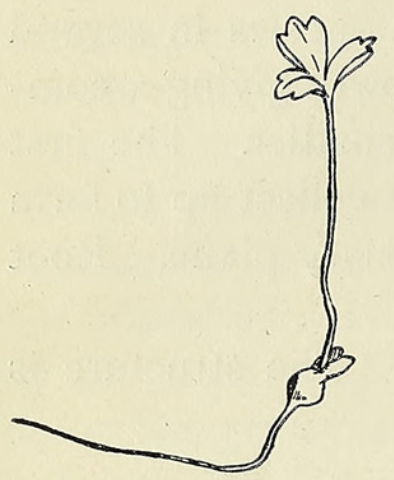

TEXT-FIG. 3. Anemone nemorosa. Seedcoat removed. $\times 1 \frac{1}{3}$. season. The plumular anatomy shows a ring of small collateral bundles widely separated owing to the tuberous character of the axis. The individual strands frequently have a single radial row of secondary wood elements, and in consequence the wings to the diarch plate of the hypocotyl are very long and narrow.

In connexion with this species Marie ${ }^{1}$ describes individual endodermal sheaths round the separate bundles, both in the rhizome and aerial stem.

A young rhizome showed a quite normal ring of bundles, but no trace of endodermis was observed.

A. apennina seedlings are noticeable in having a single two-lobed cotyledon. Root structure is arrived at in the cotyledonary petiole as described by Dr. Thomas. ${ }^{2}$ The behaviour of the plumular strands in the tuber is anomalous and has not yet been fully worked out. In addition to the strands connecting directly with the central diarch

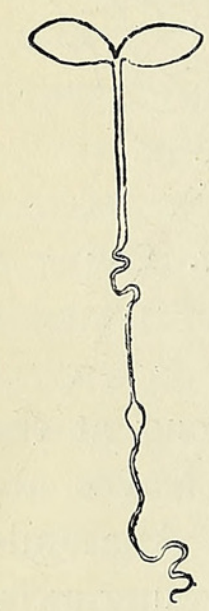

TEXT-FIG. 4. Eranthis hiemalis. $\frac{2}{3}$ nat. size. plate there are also five peripheral collateral bundles which join the root stele only at the base of the tuber.

Eranthis. The adult anatomy is unusual as regards its aerial stem in that, as in Anemone nemorosa, the individual bundles are surrounded by endodermis. ${ }^{3}$ The seedling figured (Text-fig. 4) was too young to make reliable observations on the plumular strands. A year-old seedling bearing a single (? first) foliage leaf showed endodermal sheaths to its leaf-trace strands, but no endodermis was distinguished in the tuber. The structure of the tuber will be further investigated. It shows a ring of irregular bundles connected by cambium and, within the ring, medullary vascular tissues. The xylem in all cases was of isodiametric tracheides.

Delphinium. According to Marié, both annual and perennial species of this genus have, in their adult stems, a vascular cylinder of separate

1 Marié : loc. cit., p. $5^{8 .}$

2 Thomas, E. N.: Seedling Anatomy of Ranales, \&c. Ann. of Bot., October, I9I4, p. 704 .

3 Marié : loc. cit., p. $9^{2}$. 
collateral strands of varying sizes. There would appear to be no interfascicular cambium.

The young stem, as found in the epicotyl of seedlings, has a much more regular ring of bundles connected, particularly in the perennial species, by a strongly developed ring of cambium. The number of strands supplied to the stele from each leaf is usually three. Those of the first two leaves may be two or one, and, according to M. Lenfant, ${ }^{1}$ in the adult plant of annual species the number of strands is augmented by others appearing between the median strands and the laterals.

D. formosum. This is a perennial species. The seedling has a five-fid leaf and the cotyledons show a tendency to bifurcate. At a very early age the hypocotyl shows a tuberous swelling. A short cotyledonary tube is present. The base of each foliage leaf also completely enfolds all younger structures. Near the point of insertion of the petiole the leaf-trace strands are three in number and cambial division has taken place within them. The three strands enter the ring of bundles at different points and, at the same level, some of the strands within the vascular cylinder fuse so that, at the age examined, the number of strands in the internode remains about five. Exactly which strands unite varies in different individuals and at different nodes. The inception of a complete cambial ring is at about the level of the node of the youngest fully expanded foliage leaf. The cotyledons each contain a double bundle, but no laterals are present in the petiolar region (see Thomas, loc. cit.). The double bundles join the ring at the same level as the median strand from the first foliage leaf, the laterals of which were inserted at a higher level. In the upper part of this 'double node' are present three strands derived from the second and subsequent leaves. These arrange themselves two on one side and one on the other of the plane passing through the cotyledons. The lateral strands from the first leaf fuse with the single strand mentioned above before the central portion enters the ring, so that the appearance of three strands on either side of the cotyledonary plane is lost because, though present, they unite at different levels.

The strands on the other side fuse below the cotyledonary plane, and the two plumular bundles thus formed pass down the hypocotyl, decreasing in bulk as the lower levels are reached. The cotyledonary strands have become arranged in the form of a diarch root so that these plumular bundles form the customary wings to the diarch plate.

D. occidentale. The first two foliage leaves, though of different ages, are practically opposite and at right angles to the cotyledons. This feature is of fairly frequent occurrence among the seedlings of Ranunculaceae, but in this case it is correlated with a similar anatomical arrangement. The first two foliage leaves have a single strand, instead of the usual three, and

1 Loc. cit., p. 44. 
the two strands are inserted in the vascular ring at the same level. Cambial growth begins at a somewhat earlier age in this species (see Pl. XIII, Fig. 3).

$D$. luzulinum differs from $D$. occidentale only in that the first foliage leaf has one lateral strand.

D. Ajacis is an annual and differs in several important points from the species described above. Its foliage leaves are produced much more rapidly, so that a seedling of the same age would have many more foliage leaves than that of another species. The leaf bases are not sheathing.

The bundles in the vascular ring are more numerous than in the other species. This is probably correlated with the greater production of leaves. Secondary thickening arises much later and is probably less in extent. There is a relatively large pith. This feature seems to be correlated with the larger number of bundles in the vascular cylinder. In one seedling the first foliage leaf supplies only one lateral to the ring, the other fusing with the median bundle. The central and, if present, the lateral strands of the first foliage leaf join the vascular ring at the same level as the cotyledonary traces. At the cotyledonary node there are a large number of plumular bundles. Stem structure persists for some way down the hypocotyl, differing only from that of the epicotyl in the presence of the two ' mesarch' protoxylem groups derived from the cotyledons. The bundles gradually close up and the number is reduced till the usual six strands, three on either side of the cotyledonary plane, are reached. By reductions of the pith and closing up of the plumular tissue, root structure is established as in the other species, but at a much lower level in the hypocotyl.

Helleborus. H. foetidus is described by Marié as having ordinary dicotyledonous structure in its stem. That is to say, it has a ring of bundles connected later by cambial growth.

The genus is noted for having a sinuous endodermis dipping down between the bundles.

The seedlings and young plants examined showed a noticeable similarity in all the nodes except the cotyledonary node.

Each leaf supplies three strands to a somewhat slender vascular cylinder, but sometimes one or both laterals are missing in the early leaves. The cotyledonary node is quite normal and possesses a pith which persists a short way down the hypocotyl.

Nigella. The vascular system of the adult stem consists of a ring of strands varying in number and size. Cambial growth may be found at the base of the plant in some species. The seedling structure is similar to that of Delphinium Ajacis, but differs in a peculiar distinctness of the individual bundles.

$N$. hispanica. A meristematic ring does not appear till a very late date, and then it is only in the region of the cotyledonary node. The 
bundles in the internode are very numerous and well marked off from the ground tissue (see Text-fig. 5).

The nodes and internodes are all perfectly distinct, though the first two or three leaves may not have their full complement of strands at the point of insertion. The cotyledonary node is quite typical (see Text-fig. 6).

$N$. aristata shows similar features.
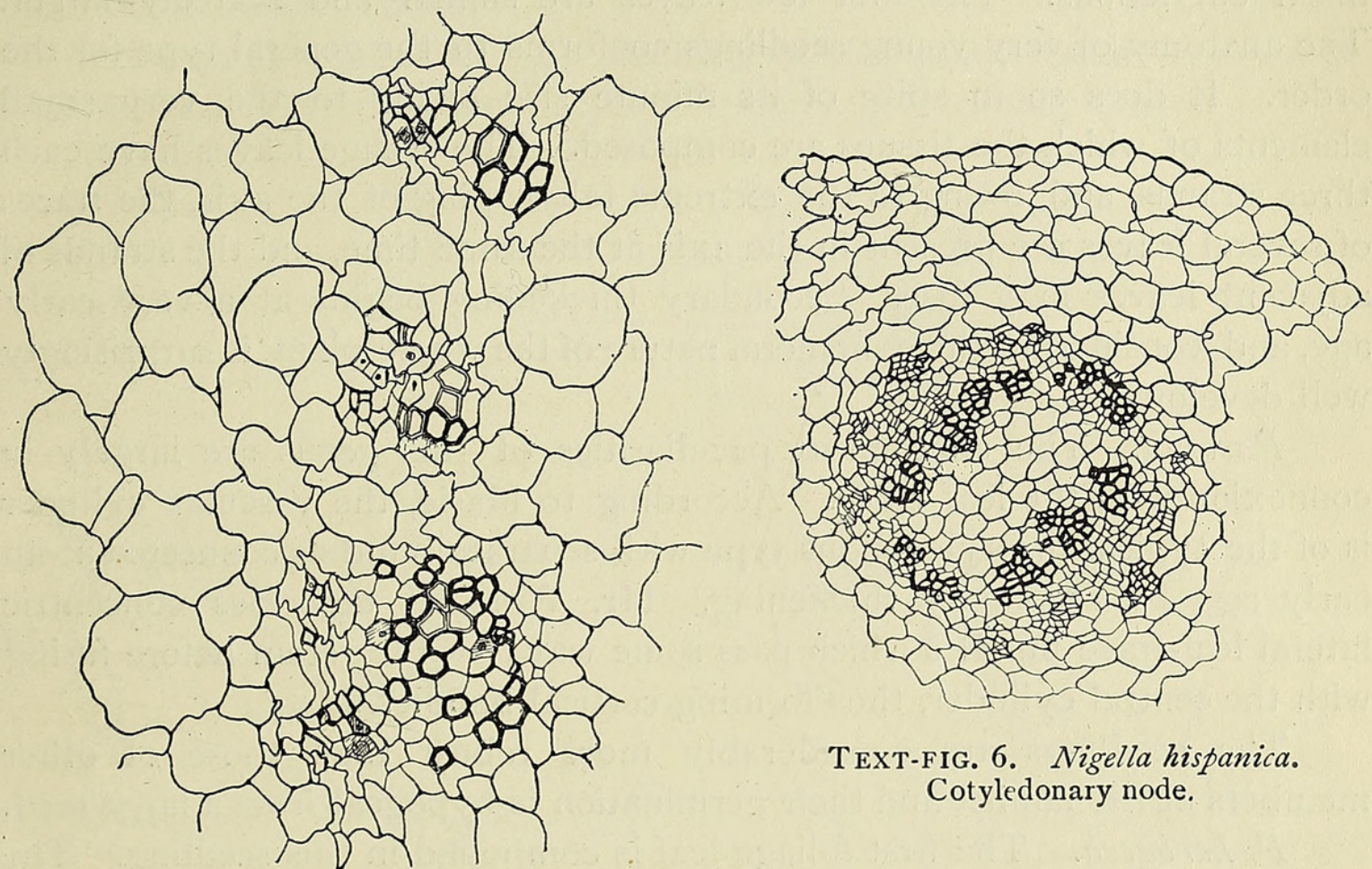

TeXT-FIG. 6. Nigella hispanica. Cotyledonary node.

TEXT-FIG. 5. Nigella hispanica. Part of vascular ring in first internode.

Adonis. Perennial species have an extensive cambial development in the adult plant, whereas $A$. aestivalis retains a ring of separate bundles (Marié).

The seedling of the latter species has two large lanceolate cotyledons and a well-marked cotyledonary tube. The first two leaves are much cut up and in an opposite pair at right angles to the cotyledons. Later leaves show the usual two-fifths phyllotaxis. The anatomy of the seedling strongly resembles that of Delphinium Ajacis, except that it is the first two foliage leaves which are inserted at a single node. These frequently have both laterals, whereas there are none in the cotyledons. Pericyclic arcs composed of transfusion-like elements are seen at an early age outside the larger bundles.

Myosurus. The whole plant of $M$. minimus is very minute. The part above ground consists of a very short stem, bearing a number of needle-like leaves at the ground level, continued into a long peduncle terminating in a single flower.

In well-developed specimens axillary buds are present in the axils of 
the upper and larger leaves. In the peduncle there are five or more distinct collateral bundles surrounded by a lignified pericycle several cells thick.

At the region of the insertion of the leaves the bundles have been connected up by secondary thickening so as to form a continuous cylinder only broken by the entry of leaf traces, three from each leaf.

The seedling of this plant is exceedingly small, with two minute sessile linear cotyledons. The first few leaves are similar and scarcely larger. The anatomy of very young seedlings conforms to the general type for the order. It does so in spite of its minute size owing to the very small elements of which the tissues are composed. The foliage leaves have each three strands, and, owing to the extreme telescoping of the axis, the traces of several leaves are present in the axis at the same time, and the strands of adjacent leaves may fuse. Secondary thickening begins at a very early age, and, considering the ephemeral nature of the whole plant, is surprisingly well developed.

Paeonia. The anatomical peculiarities of this genus are largely in connexion with the leaf trace. According to Marié, the vascular cylinder is of the typical dicotyledonous type with separate bundles connected at an early age by secondary thickening. Mr. Worsdell describes concentric lateral leaf-trace bundles which pass some way down the stem before fusing with the central cylinder, thus forming cortical bundles. ${ }^{1}$

The seedlings are considerably more robust than those of other members of the family, and their germination is hypogeal from a large seed.

$P$. herbacea. The first foliage leaf is compound in this seedling. The cotyledonary node and hypocotyl swell in a tuberous manner at an early age, but this is chiefly secondary, being largely due to rapid growth of the normal cambium.

The vascular cylinder, though bulkier, is of the usual type found in seedlings of perennials.

The leaf-trace bundle is very large and fan-shaped and contains much secondary tissue. Large buds are present in the axils of the cotyledons, and the cotyledonary node is rather drawn out. The pith is persistent and flanked by plumular bundles, which are augmented by the half-bundles from the cotyledons.

$P$. arborea is similar in general structure, though it lacks the tuberous swelling at the age examined. The first foliage leaf supplies five strands to the stele in place of the usual three. A slight doubleness in the median strand of the first foliage leaf is to be observed.

$P$. anomala and $P$. officinalis are similar. In the former, secondary thickening appears to be much later, but this may be not so much a question of age as of rate of production of leaves, for age is here estimated by a number of leaves. 
Aconitum. Marié has described the adult anatomy in a number of species. The vascular system of the stem consists of separate collateral strands arranged either on a single circle somewhat unevenly, as in Delphinium, or on two or three circles, thus resembling Thalictrum. The tuberous rhizome may exhibit a ring of bundles united by a cambium, or it may show anomalous structures such as the ring of concentric bundles found in Aconitum Anthora.

In external appearance the seedlings of this genus resemble those of Ranunculus. There is a tendency to the early formation of tubers.

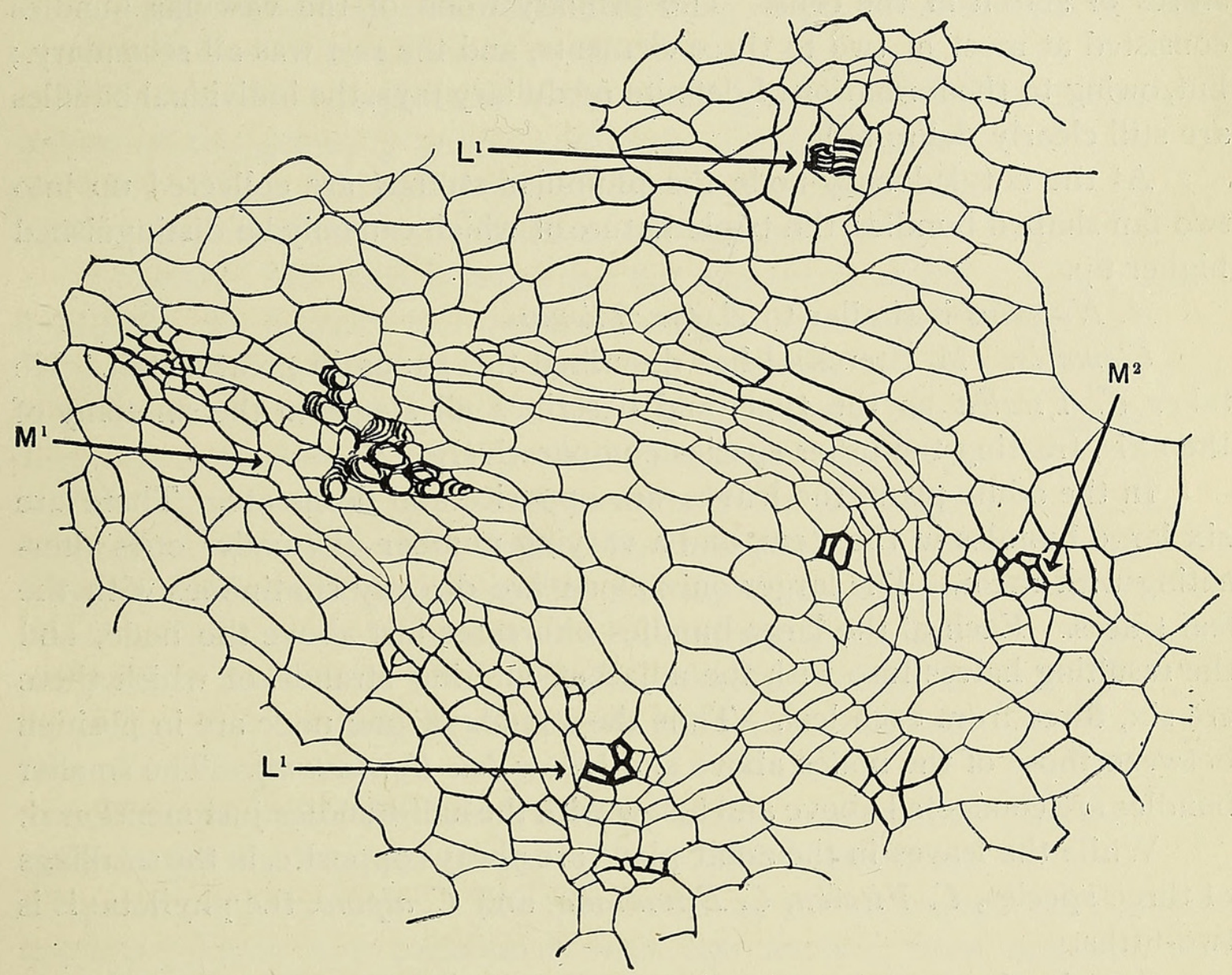

TEXT-FIG. 7. Aconitum Wilsonii. First plumular node. $\mathrm{M}^{1}, \mathrm{~L}^{\mathbf{1}}$, trace of first leaf; $\mathrm{M}^{2}$, median strand of second leaf.

Anatomically, the seedlings are noteworthy in possessing small leaftrace strands, so that the primary xylem is slight in extent. To compensate for this a cambial ring is instituted very early, but the amount of xylem formed is not great and there are large principal medullary rays which define the bundles even after the formation of secondary thickening.

A. Wilsonii. The seedlings of this genus are glabrous and have a fairly large, long-stalked, reniform foliage leaf. At an early stage there is a tuberous swelling of the hypocotyl and lower part of the epicotyl.

A rather young seedling, with a single expanded foliage leaf, showed an almost complete cambial ring at the first plumular node (see Text-fig. 7). 
There were only two lignified elements in connexion with the traces of the second foliage leaf, so that at a slightly older stage the woody tissue is almost entirely secondary. Except for these features the young seedling resembles Aquilegia, even to the angular divergence of the three bundles from each leaf.

A. pyrenaicum was examined at an age intermediate between the two stages of $A$. Wilsonii. It appeared to be essentially similar. The foliage leaves are somewhat smaller than in the last species, and covered with short hairs. Tuber formation had just begun and was accompanied by large stores of starch in the cells. The primary wood of the vascular bundles consisted at most of two to three elements, and the rest was all secondary; but, owing to the formation of definite medullary rays, the individual bundles are still clearly delimited.

At the cotyledonary node the plumular strands are collected up into two fan-shaped bundles, the triple nature of which can only be distinguished higher up.

A. Napellus is similar to $A$.pyrenaicum.

Clematis. M. Sterckx ${ }^{1}$ has described this genus in great detail. $\mathrm{He}$ takes $C$. Vitalba as the type, and describes all stages in the anatomy of the axis, treating the other species comparatively.

In the adult plant the leaves are opposite and decussate. There are six large bundles in the stem, and a varying number of smaller ones alternating with them. The larger ones alone are directly continuous with the leaf traces. Each of the large bundles bifurcates just above the node, and the'resulting halves fuse with the adjacent entering strands, of which there are six, three from each leaf. Thus the strands of one node are in position between those of the nodes above and below (cf. Equisetum). The smaller bundles are connected above and below with the half-bundles just mentioned.

While the leaves in the adult plant are always opposite, in the seedlings of three species, C. Vitalba, C. Davidiana, and C. alpina, the phyllotaxis is two-fifths.

Germination may be epigeal or hypogeal, and in some cases both conditions may be found in one species, e.g. C. orientalis.

The seedling anatomy of the spiral forms strongly resembles that in Aquilegia, but that of the opposite-leaved forms is specialized in connexion with this habit.

C. Vitalba. The cotyledons are slightly stalked and epigeal. The first few foliage leaves are ovate and long-stalked with irregularly serrate margins. The phyllotaxis is two-fifths and the internodes are very short (see Text-fig. 8).

According to Sterckx it is not till about the fifteenth foliage leaf that the arrangement becomes opposite and decussate. 
The vascular axis consists of a ring of strands smaller in number than in the adult plant. The foliage leaves each supply three strands, and their insertion is trilacunar except in the case of the first leaf, whose strands unite at the point of entry. Secondary thickening is present at and near the cotyledonary node in a seedling with three expanded foliage leaves. This is a slightly later appearance than in Aquilegia, but otherwise the structure is very similar.

C. Davidiana is very similar to C. Vitalba in all respects. This species was not described by M. Sterckx.

C. alpina was only examined in a young stage, but it seemed to correspond with the last two species.

The opposite-leaved habit in the seedling stage, found in the remaining species of this genus, is unique within the family Ranunculaceae. There is considerable variety in the behaviour of this type, even within the limits of one species.

C. recta. The seed is large and flat and germination hypogeal. M. Sterckx has described epigeal specimens. ${ }^{1}$ The cotyledons have somewhat long petioles. The plumule emerges from within a short cotyledonary tube. The first internode is usually short, the later ones vary in different specimens; but most commonly the third and subsequent ones are elongated. The first few pairs of leaves are reduced to mere cup-like growths of concurrent scales. The later leaves are ovate with entire margins and are smaller than those of C. Vitalba. Axillary buds in the foliage and cotyledonary leaf axils are a feature of this type of seedling.

The anatomical features are very variable, and in the

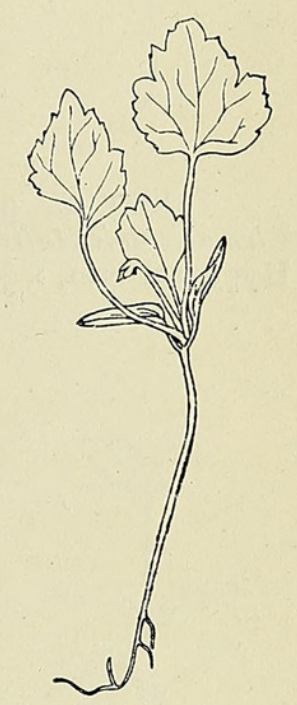

TEXT-FIG. 8. Clematis Vitalba. $\frac{1}{2}$ nat. size. early stages the strands are not always differentiated in all parts of their course. The internodes contain four separate collateral bundles. These are continuous with one another from node to node instead of alternating as in the adult. The leaf traces are three from each leaf, and the laterals of adjacent leaves join one another and are inserted in the middle of one opposite pair of the four strands which open out to receive them, whereas the median strands are inserted in the middle of the other pair. Sterckx figures a complete approximation of the alternate half-strands at the nodes which I have not succeeded in observing, but it seems probable that this may be effected at a later age. Just above the cotyledonary node two of the strands bifurcate, and thus the usual nodal arrangement of three groups on either side of the cotyledonary plane is obtained and root structure is arrived at in the usual manner.

C. orientalis. Germination may be epigeal or hypogeal. The former 
seems correlated with an earlier development of foliage leaves. The first few pairs of leaves in the hypogeal form are frequently reduced to minute concrescent scales (see Text-fig. 9). The scale leaves frequently supply only one strand to the vascular cylinder, and the internodal strands may be reduced to three.

C. Flammula. The cotyledons are epigeal (see Text-fig. IO). There is a tendency to increase the number of vascular bundles to five or six in some of the internodes, otherwise it is similar to $C$. recta.

C. viticella is of the hypogeal type and is remarkable in having three strands to its cotyledons. The lateral strands are inserted in the gaps between the three plumular strands on each side, and for a short distance a tetrarch arrangement is present. The intercotyledonary poles soon die out and a diarch root is formed (see Thomas, loc. cit., p. 7o6).

TeXT-FIG. 9 . Clematis orientalis. Hypogeal form,$\times \frac{2}{3}$.

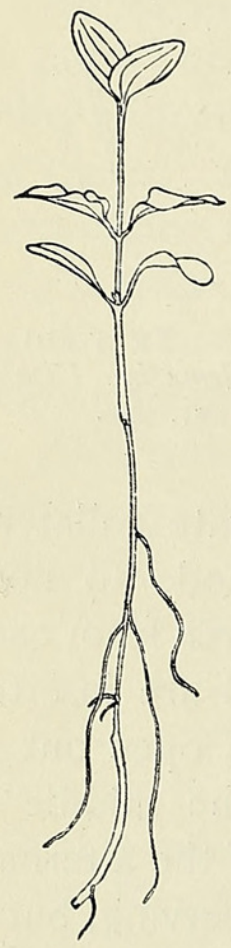

TEXT-FIG. IO. Clematis Flammula. $\times \frac{1}{2}$.

C. Hendersonii and C. integrifolia resemble $C$. viticella.

As a result of his careful study of the genus Clematis, Sterckx was led to the conclusion that the opposite-leaved form has been derived from a form with leaves arranged on a spiral phyllotaxy of two-fifths. An investigation of the seedlings of the genus led the writer independently to the same conclusion. The considerations on which this hypothesis is based are as follows:

(a) The phyllotaxis of C. Vitalba in the seedling is two-fifths, and only after the formation of about fifteen foliage leaves is the opposite and decussate arrangement arrived at. This seems suggestive on the basis of the principle that ontogeny repeats phylogeny.

(b) The opposite leaves and long internodes, possibly correlated with the climbing habit, are not found elsewhere in Ranunculaceae, whereas the two-fifths phyllotaxy and relatively short internodes found in the seedlings of C. Vitalba, C. Davidiana, and C. alpina are characteristic of the seedlings of this order, and this leaf arrangement is usually maintained in the adult plants.

(c) In the flower, a notably conservative part of the plant, although the sepals are opposite, the stamens and carpels are spirally arranged.

The consideration of these points, in default of evidence to the contrary, would seem to justify the conclusion that the genus Clematis is derived from some form similar to that found in other members of the order, and 
that the special characteristics are possibly correlated with its climbing habit.

Ranunculus. Marie considers this genus to be the type from which all the others have been derived, and Professor Jeffrey found in this genus a siphonostelic condition with internal and external endodermal sheaths.

The anatomy varies in the different species. The aerial axis contains a cylinder of separate strands, either with a single endodermis, which may be sinuous, or with a separate endodermal sheath to each bundle. Of the species here described, $R$. acris, $R$. sceleratus, $R$. arvensis, $R$. parviflorus, and probably $R$. repens and $R$. bulbosus show the former condition, while
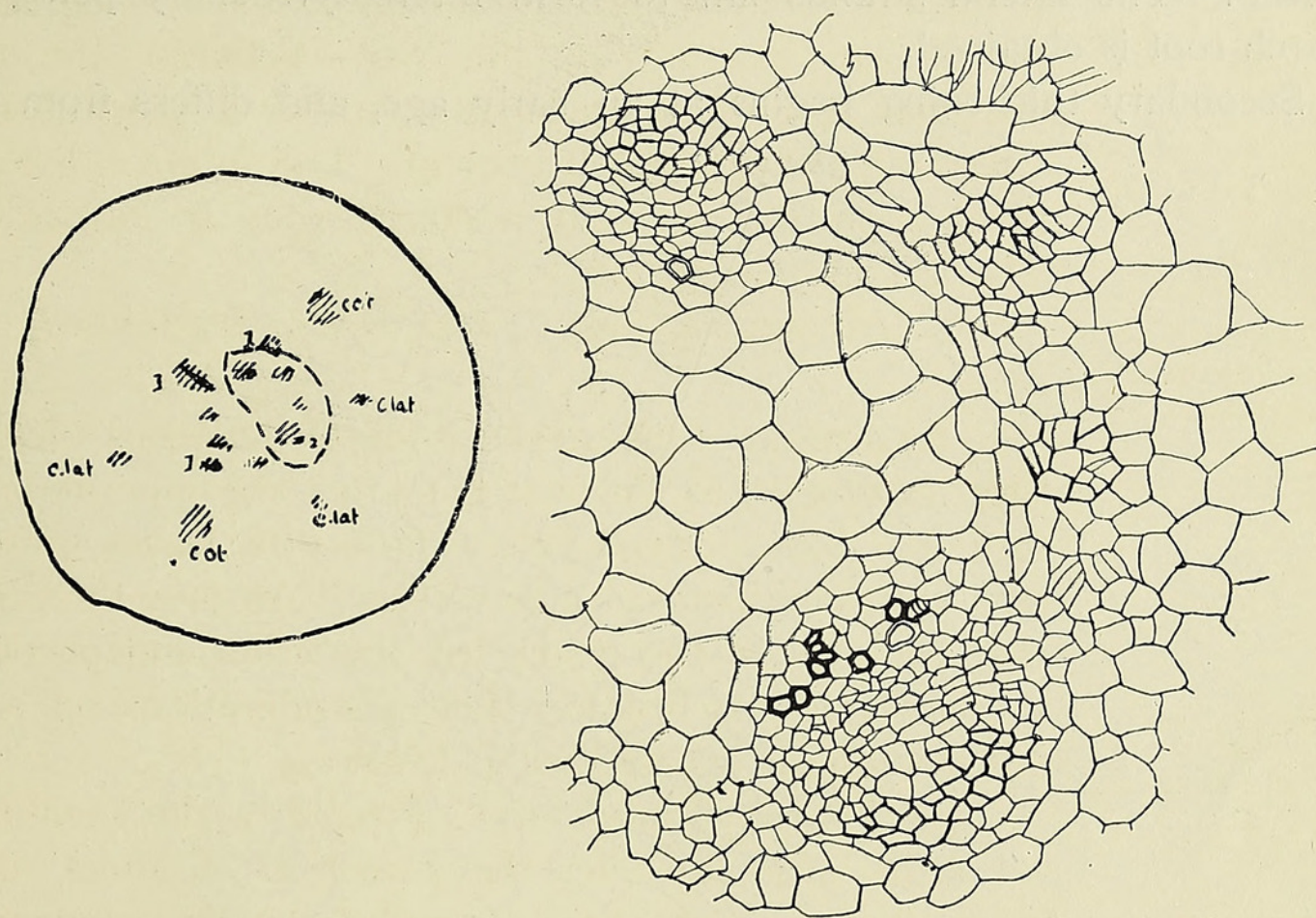

Text-Fig. I I. Ranunculus arvensis. First plumular node, showing part of ring of bundles. Inset shows relation to other parts of section.

$R$. hederaceus, $R$. aquatilis, $R$. auricomus, and $R$. Ficaria present the latter, which is also found in the rhizome of $R$. acris and $R$. repens. An endodermis is found round the petiolar strands as in most plants of the genera of this family.

$R$. Ficaria stands out owing to its single cotyledon and tuberous habit. The seedling of $R$. arvensis is relatively large.

The seedlings fall naturally into four groups when considered anatomically.

I. $R$. arvensis has been fully investigated by $M$. Nihoul. ${ }^{1}$ This species shows a good series of leaf form, from the well-developed compound leaf to the simple ovate cotyledon. It is chiefly remarkable in showing 
none of the peculiarities of anatomy exhibited by the other species, and conforms to the general type described for the family.

The vascular cylinder consists of a ring of collateral bundles (see Text-fig. II).

Each foliage leaf supplies three leaf-trace bundles and the insertion is trilacunar. The plumular strands reduce to six above the cotyledonary node. The cotyledons also usually have three strands at their base, though one or both of the laterals may be missing (see Text-fig. I I, inset).

At the cotyledonary node the central strands behave as usual, and the laterals insert themselves in the gaps of the plumular tissue (cf. Clematis viticella). The lateral strands fail to form intercotyledonary poles, and a diarch root is obtained.

Secondary thickening begins at an early age, and differs from that

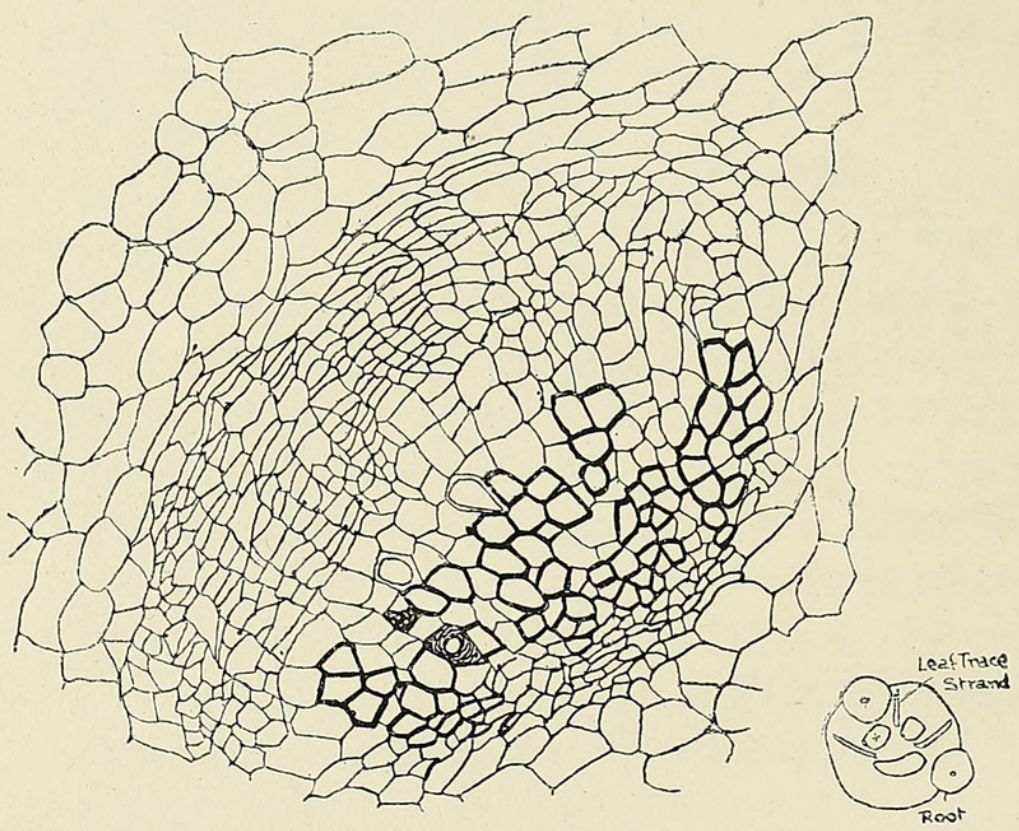

TEXT-FIG. I 2. Ranunculus arvensis. First plumular node, primary structure disguised by secondary thickening. Inset shows relation of part shown $(x)$ to other parts of the section.

described above for other genera of the order in the absence of principal medullary rays and consequent production of a continuous vascular cylinder. The condition thus produced is suggestive, in appearance, of a siphonostelic ring, but is clearly secondary in origin (see Text-fig. I2). An endodermis could not be detected in young seedlings, but in older plants indications were sometimes seen.

2. $R$. acris may be taken as a type of the second group of forms found in this genus. The seedlings of this species show considerable variation. One young seedling bearing only a single foliage leaf appears very similar to $R$. arvensis at the same age, but it is very much smaller in size and the entering leaf traces have a horizontal course. The usual six plumular strands at the cotyledonary node are not distinguishable. In another seedling of apparently the same age, the primary vascular bundles 
are connected up by what appear to be secondary elements arranged in radial rows. An endodermis is distinguishable in connexion with the strands in the leaf and round the axial cylinder. In this particular seedling an internal layer is not distinguishable, but older seedlings show an internal layer also, in communication with the outer through the leaf gaps.

This endodermis is never diagrammatic and is often very difficult to demonstrate. It can sometimes be detected in an unstained section by its highly refractive walls. Gentian violet and Bismarck brown, the double stain used for most of the work described in this paper, will only show up the endodermis in very exceptional cases, and cannot be relied upon. Phloroglucinol as used by Professor Jeffrey was most satisfactory, but as
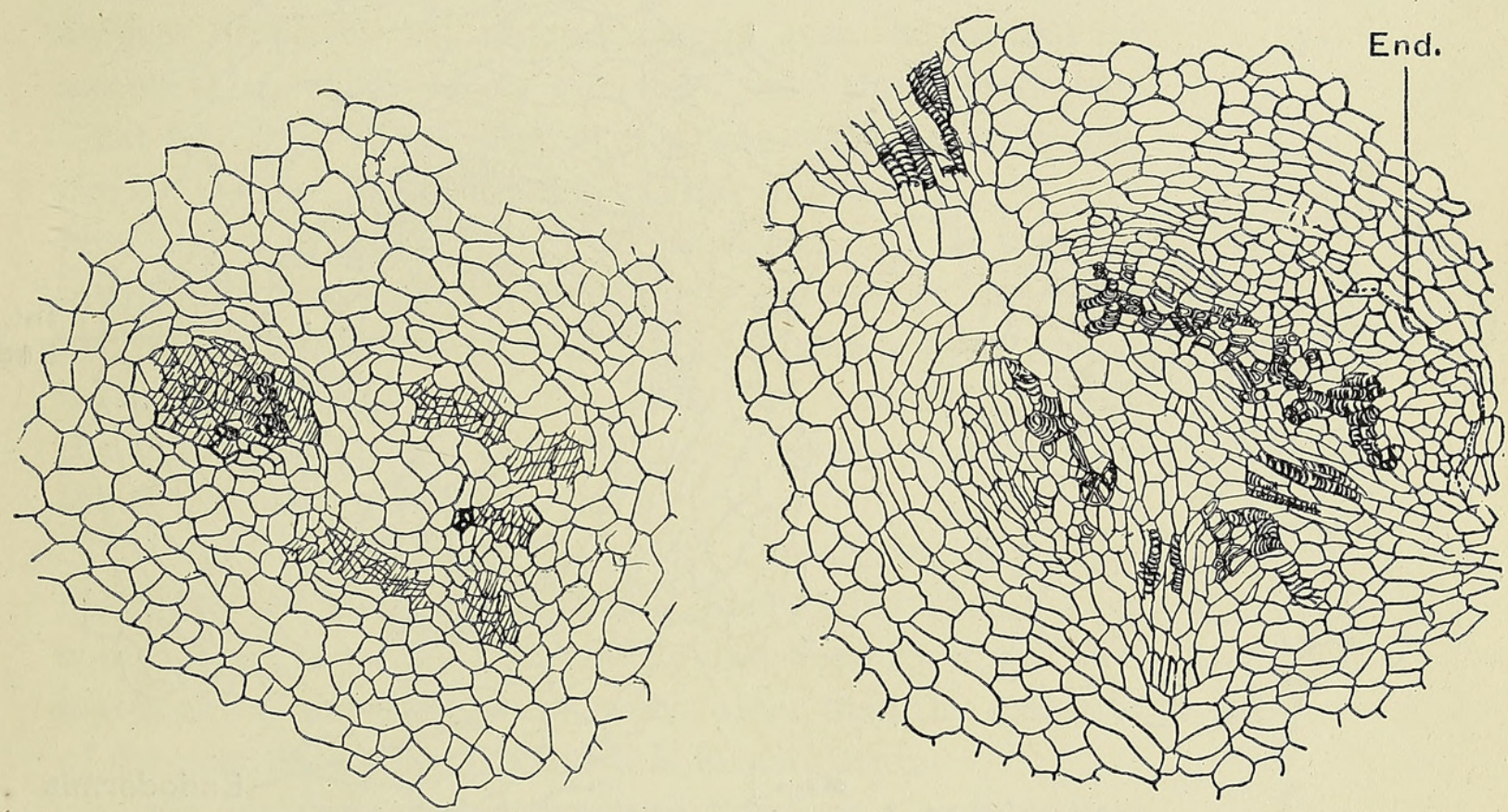

TEXT-FIGS. I3 and I4. Ranunculus gramineus. First plumular node at two stages under the same magnification. End., Endodermis.

this cannot be used for permanent preparation, an attempt was made to find a suitable stain for the purpose. A saturated spirit solution of malachite green, counterstained with borax carmine or eosin in clove oil, was found the most satisfactory relatively permanent stain, although it fades rather quickly.

In quickly growing seedlings a rapid increase in girth causes a tangential stretching of the elements, particularly of the phloem (see Pl. XIII, Fig. 4). In extreme cases this may disguise the radial arrangement of the elements.

A slow growing autumn seedling cut in the spring showed an entire lack of this feature.

Lateral roots frequently occur at the cotyledonary node.

$R$. parviflorus shows cambial growth almost before the primary wood 
elements are differentiated. There is marked tangential extension of the phloem elements at a very early age.

R. gramineus. The cambium does not appear quite so early in this species, and thus some of the primary elements may be distinguished (see Text.fig. I4). Both internal and external endodermis can be demonstrated in the older seedlings (see Text-fig. I6). The tangential extension does not take place to any great extent as there is little increase in girth of the stem (cf. Text-figs. I 3 and $I 5$ with 14 and 16 on the same scale). The axis in this and other species is very telescoped, and in consequence the wood elements are short and the strands sinuous in their course. There are no distinct principal rays between the bundles, so that their identity is almost lost.
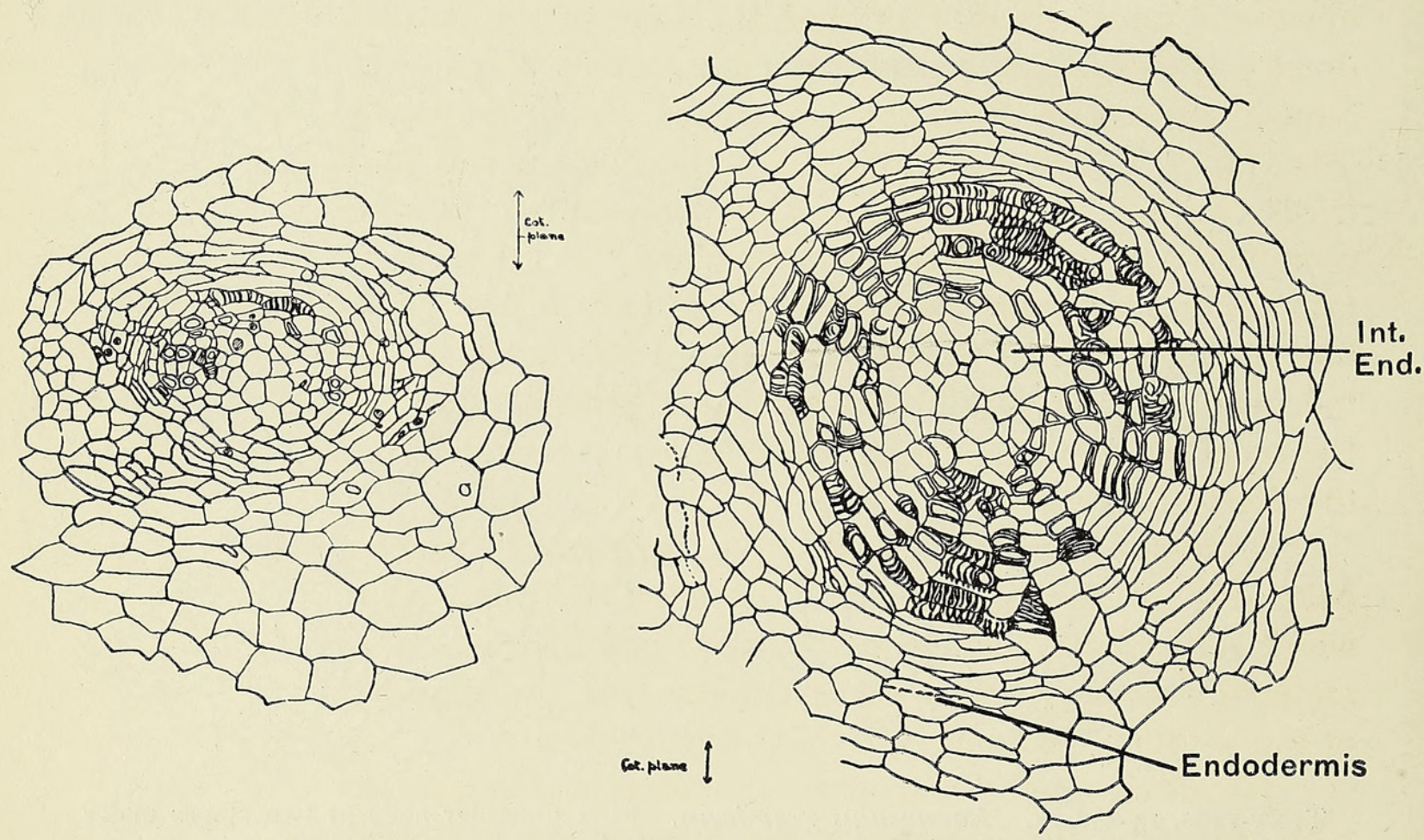

TeXt-Figs. I5 and 16. Ranunculus gramineus. First plumular internode at two stages. The same seedlings and magnification as in Text-figs. I 3 and I4.

$R$. bulbosus shows separate strands at an early stage, and in general resembles $R$. gramineus.

$R$. auricomus is similar to $R$. gramineus. The individuality of the primary strands is more obvious in this species.

$R$. repens shows extreme tangential stretching of the vascular elements, even in the very young stages, so that the long dimensions of the tracheides appear in transverse section. This seems to be due to the fact that the vascular cylinder is wider than it is long.

3. The aquatic species possess elongated internodes (except the first) in which there are distinct and separate vascular bundles.

$R$. sceleratus. There are six definite strands in the internode. There is a tendency for these to be lost at the node, but at the cotyledonary node 
the six phloem groups are quite distinct. The elements are much less compactly arranged than in the other species.

$R$. hederaceus. The internodal strands may be two, three, or six in number. At the node there is a ring-like joining-up showing secondary thickening, but the individual strands can still be distinguished although a distinct internal and external endodermis is present.

$R$. aquatilis and $R$. Flammula are similar. The internal endodermis is the more marked, though both are present at the node.

4. R. Ficaria. The apparently single-lobed cotyledon seems to be directly continued into the main root. The tuber is really the first lateral root, and arises later. The first foliage leaf appears to arise at its apex and forces its way through the base of the cotyledonary petiole. A second lateral root is formed at almost the same level, but does not store food (see Text-fig. 17). The anatomy is somewhat special and needs further investigation. The composition of the plumular strand is difficult to elucidate. It is brought into contact with the cotyledonary system at the node, but immediately below the lateral appears again as an independent unit continuous with the vascular axis of the tuberous root, whereas the cotyledonary strand forms the diarch root stele.

Professor Jeffrey ${ }^{1}$ examined a number of species belonging to the type which I have called group 2, of which $R$. acris has also been fully described by him. His material was apparently somewhat older than the majority of the seedlings examined in this investigation.

He interpreted the structure found as a siphonostele with leaf gaps through which the internal and external phloeotermal layers are connected, and from this tubular

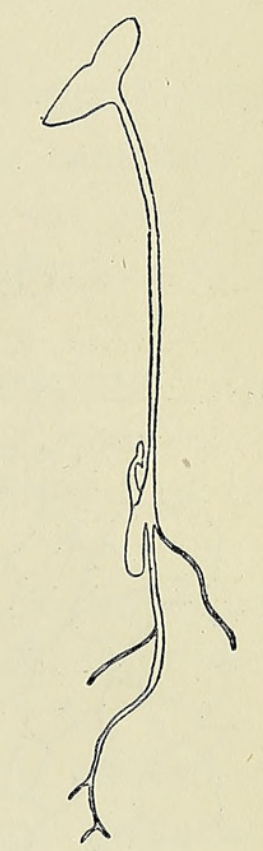

TEXT-FIG. I 7 . Ranunculus Ficaria. Nat. size. stele he considers that the ring of bundles has been derived by overlapping and lengthening of the leaf gaps and loss of endodermis.

Professor Jeffrey, in company with other anatomists, seems to have used terms, such as siphonostele, describing vascular structure as applying to primary tissues only. Whatever may be the significance of the endodermis, it has been shown that the tubular appearance of the vascular system in the genus Ranunculus is due to secondary tissue, and hence the term siphonostele, as now used, cannot be correctly applied to the structure.

The differences between the vascular structure of Ranunculus seedlings and more typical forms, irrespective of the question of endodermis, are as follows :

1. The secondary wood elements are irregularly intermingled with 
parenchyma cells, and there are no true medullary rays. This feature is found in the majority of the species, at the nodes in the aquatic species and in the secondary wood of $R$. arvensis, which is otherwise quite comparable in its seedling features with such a form as Aquilegia, as it shows a quite definite ring of bundles in the early stages of the seedling.

2. The leaf-trace strands have little primary xylem in their axial portions and its place is taken by very early formation of secondary tissue. This feature is found also in Aconitum, but there is no siphonostelic appearance in that genus owing to the formation of wide principal medullary rays.

3. The secondary xylem consists largely of isodiametric tracheides and the elements are frequently tangentially elongated. These features

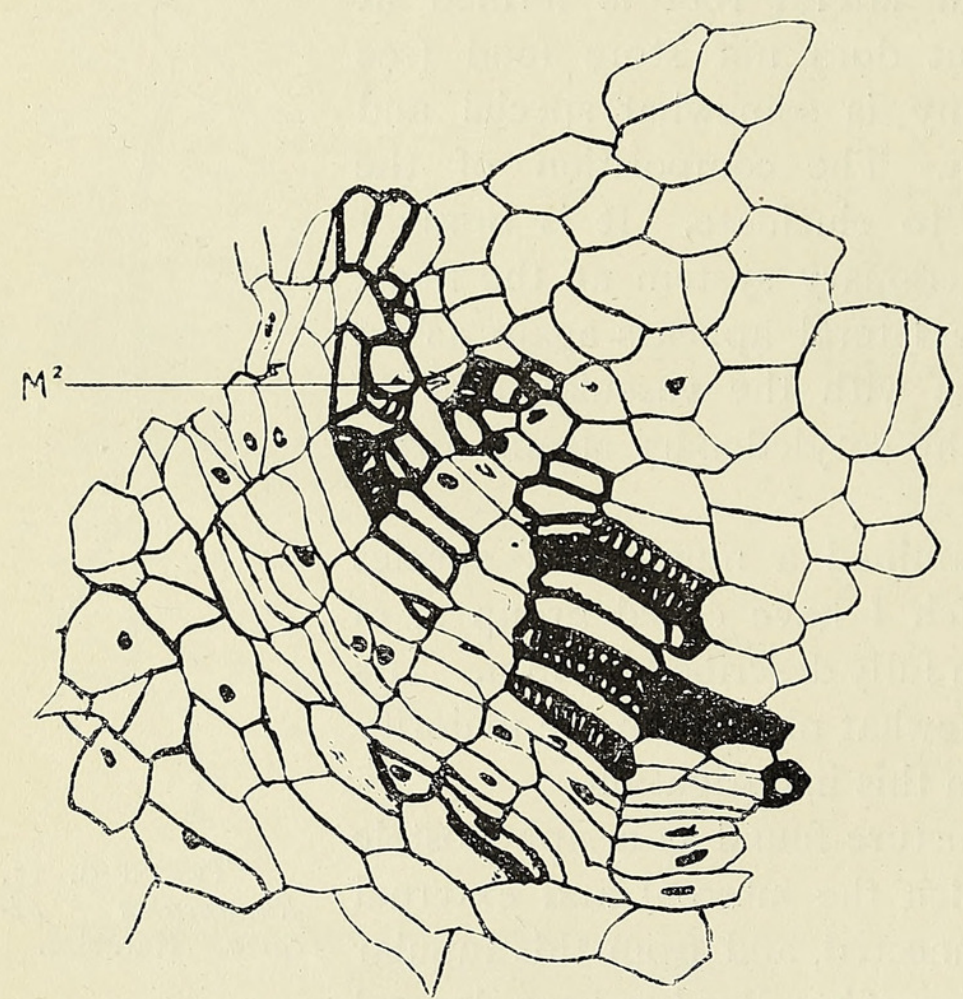

Text-fig. I8. Trollius asiaticus. Part of first plumular node. $\mathrm{M}^{2}$ is median trace of second leaf. seem to be due to the telescoping of the axis combined with its rapid radial expansion in many of the species.

Trollius. There is a ring of bundles connected by a poorly developed cambium in the rhizome. The aerial stem possesses a ring of bundles surrounded by a sinuous endodermis and with no interfascicular cambium.

The seedlings are not unlike those of $R a$ munculus in external appearance. T. pumile showed a tendency to fusion of the cotyledons by one margin. Anatomically they also show resemblances to that genus.

$T$. asiaticus. The plumular anatomy resembles that of $R$. gramineus, but a greater development of primary tissue distinguishes it, which is observable even after the formation of a quantity of secondary tissue of the 'Ranunculus' type. See Text-fig. I8, which is part of the ring at the first node and shows distinctly the median trace of the second plumular leaf. No endodermis has been demonstrated, but the evidence is insufficient to state that it is absent. At the cotyledonary node are one or more lateral roots whose vascular system seems largely supplied by plumular tissue.

T. pumile. Only one seedling has been examined. The fusion of the 
cotyledonary petioles on one side and the fusion of their strands at the base results in an arrangement at the cotyledonary node precisely similar to that found in Ramunculus Ficaria. The plumular structure resembles that found in $T$. asiaticus.

Caltha. The stem contains a ring of bundles, each surrounded by an endodermal sheath.

The leaves of the seedling are completely sheathing and have but a single strand at the base of the petiole. The epicotyledonary structure is difficult to elucidate owing to the production of a large number of roots from the plumule. It seems to be similar to that of Ramunculus gramineus, except that a protostelic appearance is produced by the almost complete absence of pith.

\section{BERBERIDACEAE.}

Podophyllum. In the subterranean axis of this genus the bundles possess each a separate endodermal sheath and a fascicular cambium is present. They are in a single ring, while those in the aerial parts are scattered, being arranged in three or four irregular circles. The phyllotaxis is one-half. ${ }^{1}$

$P$. Emodi has a long cotyledonary tube bearing two laminae. The first leaf breaks through at the base of the tube and itself completely encloses the structures within. A lateral root frequently appears at the cotyledonary node. ${ }^{2}$

The anatomy of the seedling in this species differs little from that found in Aquilegia except in the phyllotaxy. The lateral root mentioned above appears in the intercotyledonary plane.

Berberis. This is a shrubby form and shows a large amount of lignified tissue in the form of secondary wood. Broad principal medullary rays are found which split up the wood into segments. ${ }^{3}$

In habit the seedlings of the genus resemble those of Ranunculaceae in general features, but a cotyledonary tube is almost absent and the cotyledons sessile. A similar condition was found in some of the species of Anemone, for example $A$. montana.

The anatomy of the epicotyl is similar to the generalized type described for Ranunculaceae. It resembles that of Anemone in particular in the angular divergence of the strands of the trifascicular trace at their point of insertion. The features of the cotyledonary node and hypocotyl are interesting in view of the appearance of tetrarchy in the roots of some species as described by Dr. Thomas. ${ }^{4}$ B. aquiflorum is mentioned by Mr. Sinnott ${ }^{5}$ as having as many as eleven leaf-trace bundles in the adult

1 Holm, Th.: Podophyllum peltatum ; a Morphological Study. Bot. Gaz., vol. xxvii, I 899.

2 Dickson: Germination of Podophyllum Emodi. Trans. Bot. Soc. Edinburgh, vol. xvi, I885-6.

3 Solereder's Systematic Anatomy, p. 45.

4 Loc. cit., p. 708.

${ }^{5}$ Loc. cit., p. $3{ }^{2} 2$. 
plant. The seedling shows only the usual three. The epicotyledonary anatomy is almost identical with that of Anemone. Just above the cotyledonary node the plumular bundles are as usual six in number. At the node the plumular tissue divides in the intercotyledonary plane, but leaves in the middle the protoxylem elements of the median strands. The double bundles of the cotyledons orientate themselves in the usual manner to give a diarch arrangement, and the plumular protoxylem groups thus lie on the same radius as the two phloem strands. Both pith and plumular strands die out at a somewhat lower level, and thus root structure is arrived at.

$B$. heteropoda is similar to $B$. aquiflorum.

$B$. lyceum and $B$. aristata show similar epicotyledonary features. In the hypocotyl the four cotyledonary phloem groups persist in the diagonal planes, and the protoxylem groups from the median strands of the first two plumular leaves penetrate farther into the hypocotyl than in the other forms.

\section{LARDIZABALACEAE.}

Only Decaisnea Fargesii has been obtained of this order. This and the forms to be described in the following orders are trees, and the seedlings show certain differences from the herbaceous forms of Ranunculaceae. The seedlings are larger and the internodes are elongated. The leaf-trace insertion is as usual trilacunar, but there is a larger number of strands in the vascular ring.

In Decaisnea the seedling is large with long-stalked, irregularly oval cotyledons. The first foliage leaf is compound, with three leaflets, and the second has five. The bases of the foliage leaves are not sheathing, as they are in Ranunculaceae.

The plumular internodes are long, while the phyllotaxis is the usual two-fifths. Axillary buds are present both in connexion with the cotyledons and foliage leaves.

The vascular cylinder of the axis consists of a ring of about twenty bundles which are connected at an early age by cambium. The leaf trace has the usual trilacunar insertion, but the median strand is made up of three at its point of entry into the ring. While still in the cortex the leaf-trace strands divide up, the lateral ones each into two and the central one forming a ring of about seven bundles. These latter separate into two adaxial and five abaxial strands, and rearrange themselves so that in the base of the petiole there is a complete cylinder of bundles. At the cotyledonary node the plumular strands are reduced to two flattened arcs of five bundles on either side of the cotyledonary plane. The two separate bundles of the cotyledons, derived by fusion of four at a slightly higher level, insert themselves at the ends of these arcs. The ten plumular bundles reduce to six, and the arcs close up to form a ring which persists far down the hypocotyl and is similar to that found in the epicotyledonary region. Diarch root 
structure is slowly formed by approximation of phloem and xylem groups alternately as described by Dr. Thornas. ${ }^{1}$

\section{MAGNOLIACEAE.}

The vascular cylinder in the adult plant consists of a ring of collateral bundles connected by cambium and a large amount of secondary thickening. In Magnolia and Liriodendron there is a complete cylinder of bundles in the base of the petiole, ${ }^{2}$ and the leaf-trace insertion is multilacunar. ${ }^{3}$

There is a ring of bundles in the seedling petiole, but they are reduced to three in the base of the petiole, whereas in the adult plant, according to Worsdell, ${ }^{4}$ rearrangements take place largely in the cortex of the stem. This condition may be compared with what was found in the seedling of Decaisnea.

Magnolia. Two species of this genus have been examined. The seedlings are large, with practically sessile cotyledons, elongated internodes, and a phyllotaxis of two-fifths. The foliage leaves are large and ovate.

M. acuminata. The petiole contains a ring of six bundles which reduce to three in a similar manner to that found in Decaisnea, but above the point of insertion of the leaf base. The second foliage leaf has completely enfolding stipules, whose two strands fuse on the side of

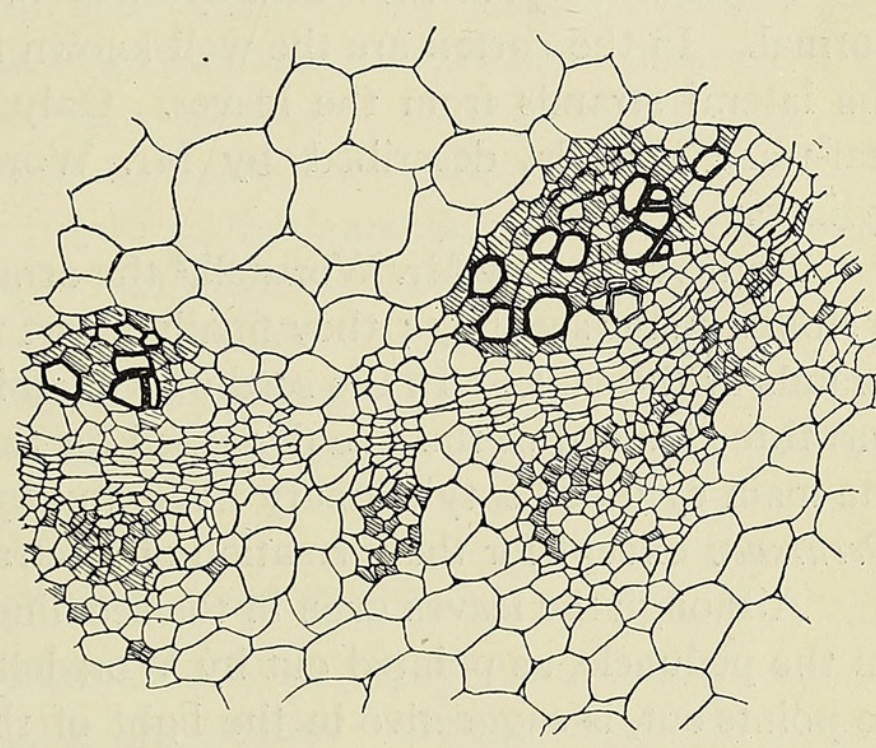

Text-Fig. 19. Magnolia acuminata. Part of vascular ring, first plumular internode.

the axis opposite the leaf insertion and join the ring there, making a minute fourth member to the trace. The stipules of the first leaf are not sheathing and contain no vascular strand. The ring of bundles in the axis is well marked and similar to that of Decaisnea. Secondary thickening begins at an early age (see Text-fig. I9).

The cotyledons each contain a double bundle and two laterals. The adjacent laterals from opposite cotyledons fuse and the four bundles so formed enter four gaps in the plumular vascular cylinder. Thus a cylinder,

1 Loc. cit., p. 709.

2 Matsuda, S.: On the Anatomy of Magnoliaceae. Jour. Coll. Sci. Imp. Univ. Japan, vol. vi, I $893-4$.

3 Sinnott : loc. cit., p. $3^{\mathrm{I} 2}$.

4 Loc. cit., p. 666. 
similar to that in the plumule, is formed in the hypocotyl as in Decaisnea, but in Magnolia passes into a tetrarch root (see Thomas, loc. cit., p. 7 IO).

$M$. Soulangeana is similar to $M$. acuminata.

Liriodendron Tulipifera. The seedling is smaller and the foliage leaves, which are nearly orbicular, show the apical depression characteristic of the species. The petioles have a ring of four strands, of which the adaxial one bifurcates and the halves rotate to join the central strand within the petiole. The leaf-trace strands are thus reduced to three. The stipules are not completely sheathing and show no vascular strand. Otherwise the anatomy is similar to that found in Magnolia, except that the intercotyledonary poles die out in the hypocotyl as described by Dr. Thomas. ${ }^{1}$

\section{Calycanthaceae.}

Calycanthus praecox. The cylinder of this plant seems to be quite normal. In the cortex are the well-known four inverted bundles formed by the lateral strands from the leaves. Only the central strand of the five leaf-trace strands, described by Mr. Worsdell, is inserted on the stem cylinder.

As described by $\mathrm{Mr}$. Worsdell, ${ }^{2}$ the arrangement of the cortical bundles is similar in the seedling ; they finally insert themselves on the cotyledonary strands at the node. In the seedlings examined the number of leaf traces was three instead of the five described for the adult plant. The features of the main cylinder, cotyledonary node, and hypocotyl are similar to those of Decaisnea except for the formation of a tetrarch root.

Although the leaves even in the seedling are opposite, the foliar organs on the peduncle, as pointed out by Worsdell, ${ }^{3}$ are spirally arranged. This, he points out, is suggestive in the light of the discovery by Baillon ${ }^{4}$ of an exceptional plant of Chimonanthus in which the leaves are arranged on a two-fifths phyllotaxy.

\section{ANONACEAE.}

Anona. The adult vascular cylinder appears to be quite normal. Sinnott states ${ }^{5}$ that the leaf-trace insertion is unilacunar though it consists of three strands. The phyllotaxy is one-half. Seedlings of two species have been examined. Germination is hypogeal, and the plumular internodes are long.

A. reticulata. The three strands from the plumular leaves have trilacunar insertion. The lateral strands are inserted near to the median strand, but not in the same gap. The structure of the epicotyl differs from

\footnotetext{
1 Loc. cit., p. 7 Io. 2 Loc. cit., p. 669.

4 Baillon: Sur un Chimonanthus à feuilles alternes. Adansonia, vol. ix, I868-70.

${ }^{5}$ Loc. cit., p. 312.
} 
that of Aquilegia in the phyllotaxis and elongated nodes, but the features of the cotyledonary node and hypocotyl are similar to those found in that genus.

\section{LAURACEAE.}

This order also seems to be noted as having unilacunar leaf-trace insertion in the adult plant.

The seedlings of Laurus Sassafras and L. nobilis have been examined, but in a rather old condition.

Germination is hypogeal. The first few foliage leaves are mere scales, and the phyllotaxis is two-fifths. The leaf-trace insertion in the seedling is also unilacunar, and the triple nature of the trace is only to be observed above the point of insertion. Secondary thickening in the vascular cylinder had progressed so far that it was impossible to identify the primary bundles with any certainty.

Although unfortunately so little material of Ranalean plants, other than those belonging to the order Ranunculaceae, has been obtained, it was thought worth while to include descriptions of such forms as have been examined. One reason for their inclusion was that they add a little to Mr. Sinnott's information with regard to the leaf-trace insertion, showing as they do that, even in forms with a multilacunar insertion in the adult, as in Magnolia, or unilacunar, as in Anona, the seedling may show the trilacunar form. A further reason was that although the habit in these tree forms is so different from that of the herbaceous Ranunculaceae, still the seedlings show an essential similarity.

\section{Summary and Conclusions.}

The investigation of the structure of the epicotyl in Ranalean seedlings has shown a somewhat remarkable uniformity. There are certain features characteristic of all the seedlings examined, but those of the Ranunculaceae and Berberidaceae show a much closer resemblance to one another.

The general ground plan for the group shows the following features :

(I) a two-fifths phyllotaxy ;

(2) a trilacunar leaf-trace insertion;

(3) a ring of bundles connected at an early age by a cambium which forms secondary tissue.

Although no single feature is uniformly present in its typical form, it is uncommon to find deviations, and where they occur they are usually confined to one of the characters. In addition to the general features just mentioned there are certain others characteristic of the herbaceous and shrubby forms of Ranunculaceae and Berberidaceae, as distinct from the plants with tree habit. The axis is very shortened and clothed with the sheathing bases of the petioles; the cotyledons are frequently fused into a tube at their base ; the leaf trace in the base of the leaf consists of three 
strands, whereas in the tree forms, although reduced to three at the point of insertion, there is often a larger number arranged in a ring at the base of the petiole. The plumular strands become reduced to six at the cotyledonary node. Each cotyledon supplies one leaf trace, which may be double, and a diarch root structure is formed quite high in the hypocotyl, whereas in the arborescent forms the hypocotyledonary vascular arrangement is frequently like that of the stem.

Apart from minor deviations from type, there are three main groups of exceptions to the general structural ground plan for the seedlings of the cohort.

I. Phyllotaxy. In Clematis the leaves are opposite and decussate in the adult, but it has been shown that the two-fifths spiral in the seedlings of C. Vitalba and other species changes ontogenetically to the opposite arrangement. This, taken in conjunction with the strong likeness between seedlings of this species and those of other plants of the family, is strong evidence in favour of the primitive nature of the spiral arrangement.

Calycanthus also has opposite leaves, but Mr. Worsdell has pointed out that this is probably derived from a two-fifths phyllotaxy, and the likeness between the two cases is strong support for either contention. It would seem probable that further data might provide evidence for the derivation of the one-half divergence of Anona and Podophyllum from the two-fifths condition.

2. Leaf Trace. The most notable exception to the general arrangement is found in Laurus, in which, though the material was inadequate, the insertion appeared to be unilacunar in the seedling, as in the adult. Paeonia is a somewhat curious case in which the first foliage leaf contributes, in some species, five strands to the vascular cylinder, while the later ones have the usual trilacunar insertion. In some cases the first one or two leaves of species belonging to Ranunculaceae contribute a reduced number of strands (one or two) either by the approximation of the strands at the point of entry, or by loss of one or both laterals. This seems clearly correlated with marked reduction in size in the plumular leaves concerned, and may throw some light on the very frequent absence of laterals at the base of the cotyledonary leaves.

3. The Stem Cylinder. The main departure from the type is found in the genus Ramunculus (also Trollius, Caltha, and, according to Professor Jeffrey, Anemone pennsylvanica), in which there is an internal endodermis and an appearance of a tubular stele. The latter has been shown to be a secondary formation correlated with the slight production of primary xylem found also in Aconitum, but the siphonostelic appearance in Ramunculus is due to the absence of the principal medullary rays found in that genus.

The presence of the internal endodermis in some species of Ramunculus is more difficult to explain. At the age examined, the endodermis is not 
usually differentiated in seedlings of the other genera. Its appearance in those of Ranunculus, Trollius, \&c. may be part of the precocity which is observed in the secondary thickening. This seems to be borne out by the fact that endodermis is present round the individual strands in the adult plant, not only in Ranunculus where an internal sheath is found in the seedling, but also in other plants, for instance Podophyllum, in which the seedling is quite normal. The origin and function of the endodermis has been reconsidered of late years by various writers, for instance by Professor Lang in his recent paper on the Ophioglossaceae, ${ }^{1}$ and it seems possible that its phylogenetic importance in the present instance has been over-estimated, especially in view of the specialized geophytic and aquatic habit of the species in which it is found, whereas it is absent in the more normal $R$. arvensis. The order Nymphaeaceae, the other instance of the appearance of an internal endodermis, cited by Professor Jeffrey for the Ranales, is also of aquatic habit, and the presence of an extra endodermis in the stem of water-plants is not an unusual phenomenon (e.g. it is found round the cortical leaf-trace bundles in Menyanthes).

To sum up the results of this investigation, there are two centres of special phylogenetic interest :

I. The Leaf-trace Insertion. There is a general prevalence of the trilacunar trace in the seedlings of Ranales. This strongly supports Mr. Sinnott's conclusions, based on a study of the adult plants of the cohort.

2. The Type of Vascuiar Cylinder. A single ring of bundles connected at a very early age by cambium is found almost universally throughout the seedlings of the cohort. This single ring of bundles does not appear to be a mere embryonic character, as suggested by Mr. Worsdell, ${ }^{2}$ for such forms as do not exhibit specialized morphology due to a geophytic habit show a similar structure throughout life (e.g. Helleborus foetidus and Magnolia). Interfascicular cambium is usually absent in the adult stems of the herbaceous Ranunculaceae, but it is invariably present at some stage in the seedling.

The siphonostelic appearance described by Professor Jeffrey in Ranunculus and Anemone is shown to occur also in Caltha and Trollius. Evidence is brought forward in favour of its wholly secondary origin.

In conclusion I should like to acknowledge with gratitude my deep indebtedness to Dr. Thomas for her constant advice and helpful criticism throughout the progress of this investigation.

BEDFORD COLLEGE.

1 Lang, W. H. : On the Anatomy and Branching of the Rhizome of Helminthostachys zeylanica. Ann. of Bot., vol. xxix, 1915, p. 35 .

${ }^{2}$ Loc. cit., p. 654 . 
I 80 Blackburn.-On Vascular Anatomy in some Ranalean Forms.

\section{EXPLANATION OF PLATE XIII.}

Illustrating Miss Blackburn's paper on the Vascular Anatomy of the Young Epicotyl in some Ranalean Forms.

Taken from photographs.

$M^{1} L^{1}, M^{2} L^{2}$ refer to the median and lateral traces of successive plumular leaves. cot. is the cotyledonary trace.

Fig. I. Aquilegia alpina. Transverse section at the first plumular node, showing the beginning of cambial growth. The cotyledonary tube has been removed. $\times$ Ioo.

Fig. 2. Aquilegia canadensis. Showing the arrangement of vascular strands at the cotyledonary node. $\times 80$.

Fig. 3. Delphinium occidentale. Transverse section of the stem at the first plumular node. $\times 32$.

Fig. 4. Ranunculus acris. Transverse section at the second plumular node, showing cambial growth. A few primary xylem elements are differentiated and there is some tangential stretching. $\times 40$. 


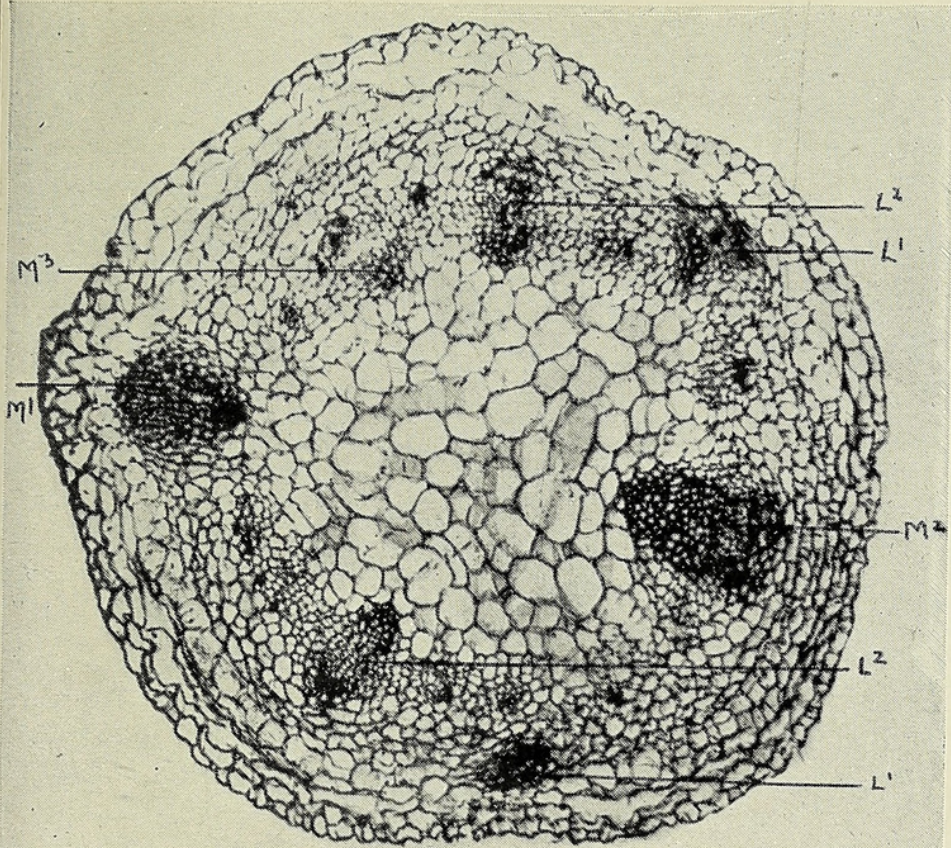

FIG. I. Aquilesia alpina.

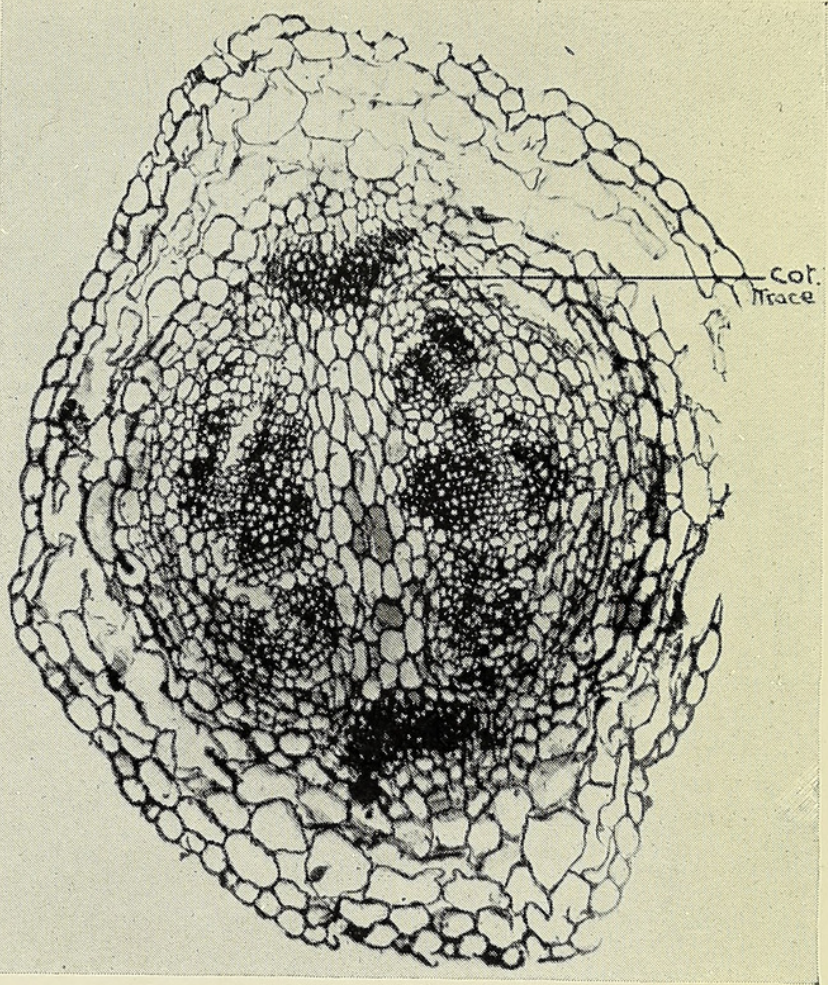

FIG. 2. Aquilegia canadensis.
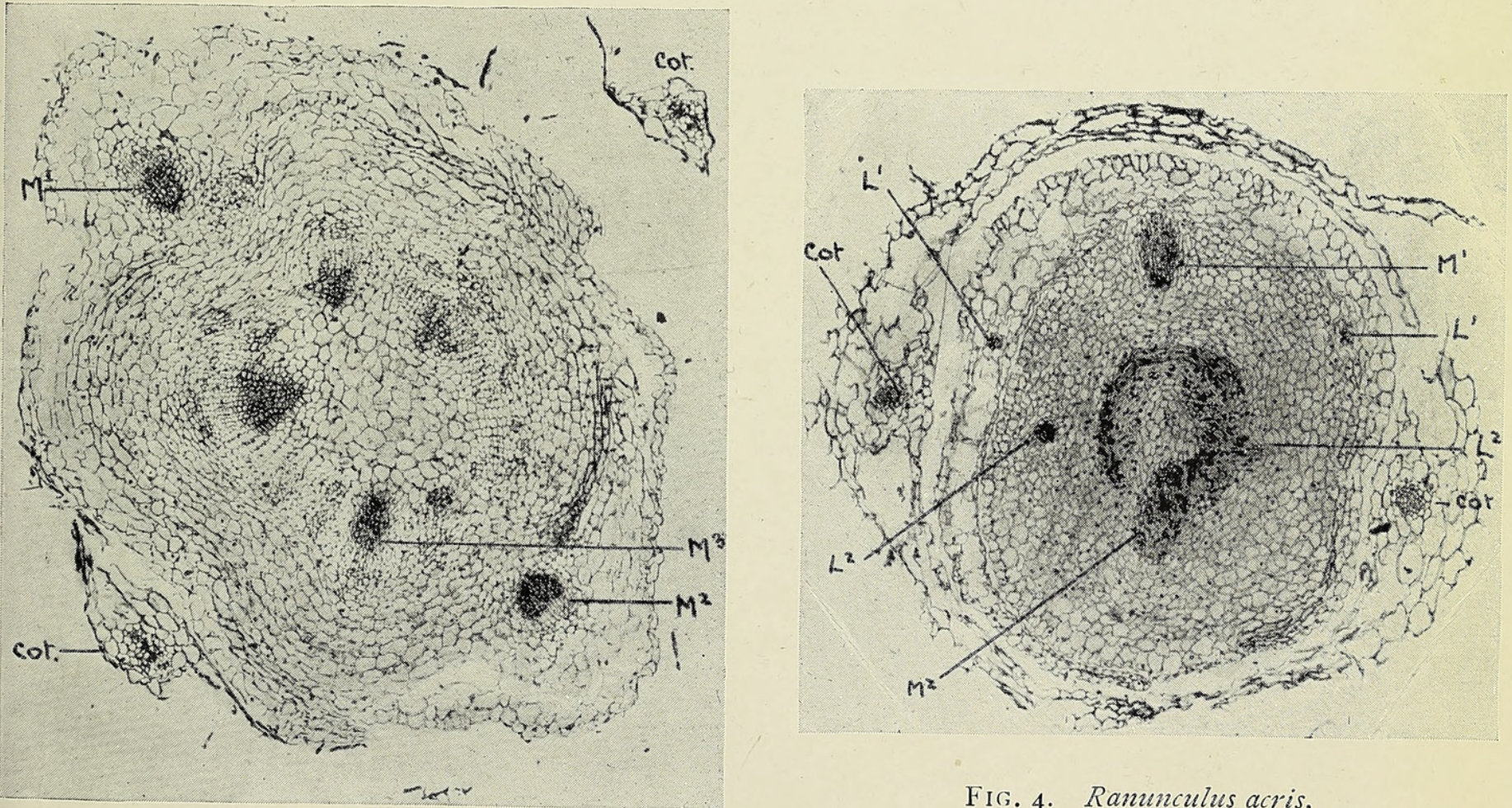

FIg. 4. Ramunculus acris.

Fig. 3. Delphinium occidentale. 


\section{$2 \mathrm{BHL}$ Biodiversity Heritage Library}

Blackburn, Kathleen B. 1917. "On the vascular anatomy of the young epicotyl in some ranalean forms." Annals of botany 31, 151-180.

https://doi.org/10.1093/oxfordjournals.aob.a089633.

View This Item Online: https://www.biodiversitylibrary.org/item/232813

DOI: https://doi.org/10.1093/oxfordjournals.aob.a089633

Permalink: https://www.biodiversitylibrary.org/partpdf/320180

\section{Holding Institution}

Smithsonian Libraries

\section{Sponsored by}

Biodiversity Heritage Library

\section{Copyright \& Reuse}

Copyright Status: Not in copyright. The BHL knows of no copyright restrictions on this item.

This document was created from content at the Biodiversity Heritage Library, the world's largest open access digital library for biodiversity literature and archives. Visit BHL at https://www.biodiversitylibrary.org. 